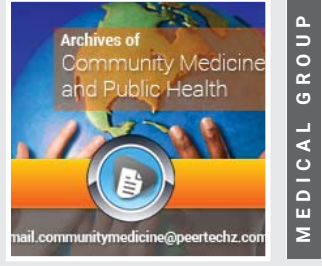

\section{Inosine Pranobex (IP) - possibilities of its use in the treatment of COVID19}

\author{
Svetozár Dluholucký* \\ Professor CSc, Pediatrician - Advisor for Research and Development, Children University Hospital, \\ Department of Pediatrics, Slovak Medical University Bratislava, Faculty of Health, Banská Bystrica, \\ Slovak Republic
}

Received: 10 August, 2020

Accepted: 31 August, 2020

Published: 01 September, 2020

*Corresponding author: Dr. Svetozár Dluholucký, Professor CSc, Pediatrician - Advisor for Research and Development, Children University Hospital, Department of Pediatrics, Slovak Medical University Bratislava, Faculty of Health, Banská Bystrica, Slovak Republic, Tel: +421905 449 038;

E-mail: sdluholucky@dfnbb.sk

https://www.peertechz.com

Check for updates
The finding that enzymes of purine metabolism interfere to the regulation of immune events is known from the findings of Giblett, et al. [1], that Adenosine Deaminase (ADA) deficiency leads to Severe Combined Immunbodeficiency (SCID), The same author described in 1975 case of T-immune deficiency caused by a deficiency of another purine metabolism enzyme Purine Nucleoside Phosphorylase (PNP). Subsequently, otherl authors have described cases of hypo to agammaglobulinemia with $5^{\prime}$-nucleotidase (5-NT) deficiency in adults [2] and children [3].

Based on these works, it was possible to postulate the hypothesis that intact purine metabolism - the balance of individual metabolites (adenosine, inosine, hypoxanthine) is a basic condition for optimal immune system function - at that time formulated by our staff $[4,5]$. At that time we found an imbalance in the activity of these enzymes in children with selective IgA deficiency $[6,7]$ and also in children with oncohematological malignancies [8]. It was found that the accumulation of adenosine (ado) and deoxyadenosine (deoado) suppressed the blast transformation of Ly after PHA and PWM in ADA deficiency, but the significance of the inosine deficiency (ado/ ino imbalance) was not clear. In the late 70's, the product Isoprinosine (inosine pranobex) appeared on the market, declared as an antiviral product with a clear effect to number of diseases of RNA and DNA viral origin (morbilli, varicella - zooster, etc.). The mechanism of this virostatic effect was unclear, but extensive research reveals that its administration activates immune processes - the production of cytokines (TNF, IL-1, IL-6, Inf), or the activity of NK cells. Its advantage was a minimum of contraindications to use (SPC). Some results from its use in our workplaces were presented $[9,10]$. Despite the good results, this preparation has been "displaced" in practice by the discovery of acyclo and ganciclovir - used mainly in DNA viral infections. At present, it is used in our country as a non-specific immunomodulator in children with recurrent respiratory infections. However, a number of works documenting its immunomodulatory and antiviral effects can be found in the literature [11-13].

\section{Suggestion}

The current COVID19 pandemic - although several antiviral agents are being declared as possible candidates for use in its severe course - does not yet have an effective drug available to alleviate, resp. suppress the severe course of the disease. In addition to currently recommended drugs, there is an opportunity to test the effect of Inosine Pranobex - Isoprinosine in influencing the course of COVID19 disease, especially in a group of high-risk patients (seniors, polymorbidity) - in a complex of other supportive treatment - in an open clinical study.

Isoprinosine at a dose of 50mg / $\mathrm{kg} / 3 \mathrm{x}$ in hazardous / severe conditions max. within first three days from the onset of the disease.

\section{References}

1. Giblett ER, Anderson JE, Cohen F, Pollara B, Meuwissen HJ (1972) AdenosineDeaminase Deficiency in Two Patients with Severely Impaired Cellular Immunity. Lancet 2: 1067-1069. Link: https://bit.ly/3bcun03

2. Johnson SM, North ME, Asherson GL, Allsop J, Watts RWE, et al (1977) Lymphocyte Purine 5'-nucleotidase Deficiency in Primary Hypogammaglobulinemia. Lancet 1: 168-170.

3. Edwards NL, Magilavy DE, Cassidy JT, Fox LH (1978) Lymphocyte Ecto-5' Nucleotidase Deficiency in Agammaglobulinaemia. Science 201: 628-630. Link: https://bit.ly/3gRbroZ 
4. Pecháň I (1984) Relationship between immunodeficiencies and disorders of purine metabolism. BLL 81: 251-227. Link: https://bit.ly/3bbUJ2E

5. Pechan I, Rendekova V, Niks M, Pechanova E, Krizko J (1984) AdenosineDeaminase and 5ase-Nucleotidase Activity of T-, and B-Lympgocytes of Human Peripheral Blood. Biologia / Bratislava 39: 381-386.

6. Dluholucký S, Pecháň I, Šváč J, Pecháňová E, Rajčanová V (1984) Activities of purine metabolism enzymes in children with IgA deficiency. Proceedings of the Czechoslovak Academy of Sciences Immunological Methods 95-99.

7. Dluholucký S, Pecháň I, Šváč J, Pecháňová E (1984) Activities of purine metabolism enzymes in healthy children and with IgA deficiency. ČSFR German Pedagogical Symposium Liberec.

8. Pecháň I, Rendeková V, Dluholucký S, Svrčková E (1981) The role of adenosine metabolism in lymphoid cells. II. Nationwide congress Čs.spol. for allergology and clinical immunology. X. Stredo - Slovak days B. Bystrica.
9. Bornemisová A, Dluholucký S, Michálek J, Oslanec J (1984) Isoprinosine in the treatment of intraocular inflammation. Optalmological National Congress. Olomouc.

10. Dluholucký S, Bubanská E, Husáková K, StančokováT (1988) Immunomodulators in the treatment of varicella-zoster infections in pediatric malignancies. Days of Pediatric Oncology, Banská Bystrica.

11. Majewska A, Lasek W, Jsanyst M, Mlynarczyk G (2015) Inhibition of adenovirus multiplication by inosine pranobex and interferon alpha in vitro. Centr Eur $\mathrm{J}$ Immunol 40: 395-399. Link: https://bit.ly/3hMmnWr

12. Sliva J, Pantzartzi CN, Votava M (2019) Inosine Pranobex: A Key Player in the Gama Against a Wide Range of Viral Infections and Non-Infectious Diseases. Adv Ther 36: 1878-1905. Link: https://bit.ly/3lyyFnA

13. Haskó G, Sitkovsky MV, Szabó C (2004) Immunomodulatory and neuroprotective effects of inosine. Trends in Pharm Sci 25: 152-157. Link: https://bit.ly/34SDP7R
Discover a bigger Impact and Visibility of your article publication with

Peertechz Publications

\section{Highlights}

* Signatory publisher of ORCID

- Signatory Publisher of DORA (San Francisco Declaration on Research Assessment)

* Articles archived in worlds' renowned service providers such as Portico, CNKI, AGRIS, TDNet, Base (Bielefeld University Library), CrossRef, Scilit, J-Gate etc.

* Journals indexed in ICMJE, SHERPA/ROMEO, Google Scholar etc.

* OAI-PMH (Open Archives Initiative Protocol for Metadata Harvesting)

* Dedicated Editorial Board for every journa

* Accurate and rapid peer-review process

* Increased citations of published articles through promotions

* Reduced timeline for article publication

Submit your articles and experience a new surge in publication services

(https://www.peertechz.com/submission).

Peertechz journals wishes everlasting success in your every endeavours.

Copyright: @ 2020 Dluholucký S. This is an open-access article distributed under the terms of the Creative Commons Attribution License, which permits unrestricted use, distribution, and reproduction in any medium, provided the original author and source are credited. 